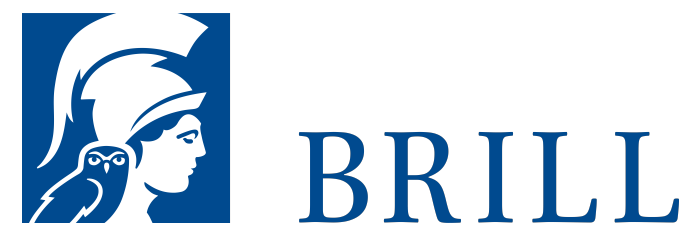

\title{
Betender Anfang
}

Identitätsstiftende Momente christlicher Morgenliturgie im

Dialog mit dem Judentum

Author: Nina Frenzel

Die historisch gewachsene und theologisch begründete Verbindung von Judentum und Christentum ist heute und zukünftig als gemeinsame Verantwortung im Hinblick darauf wahrzunehmen, dass das Lob Gottes und die Präsenz des Transzendenten auch in der modernen Gesellschaft gegenwärtig bleibt.

Der Beitrag für die liturgiewissenschaftliche Erforschung von Judentum und Christentum liegt darin, Laudes und Shacharit einander in ihrer heutigen Form gegenüberzustellen. Bisherige Untersuchungen haben sich vor allem aus der liturgiehistorischen Perspektive auf einzelne jüdische und christliche Gebete und ihre Abhängigkeiten bezogen. Der Wert dieser Arbeit dagegen besteht im Gegenwartsbezug. Gegenstand sind die morgendlichen Liturgien, so wie sie im christlichen Stundengebetbuch und dem jüdischen Siddur der Gegenwart vorliegen. In einer ganzheitlichen Betrachtung werden liturgietheologische Erkenntnisse zu den drei zentralen Kategorien von Identität, (Gebets-)Zeit und Bekenntnis gewonnen.

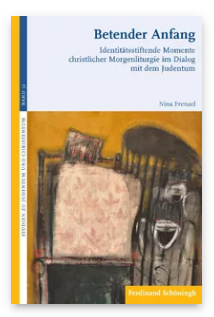

Pages: 325

Seiten, $24 \mathrm{~s} / \mathrm{w}$

Abb.

Language:

German

Subjects:

Comparative

Religion \&

Religious

Studies,

Religious

Studies,

Philosophy,

Theology \&

Science, Jewish

Studies

Publisher: Brill |

Schöningh

Series:

Studien zu

Judentum und

Christentum,

Volume: 32

E-Book (PDF)

Released online:

o5 Oct 2017

ISBN: 978-3-

657-78557-5

List price

Paperback

Publication date: o8 Sep 2017 
ISBN: $978-3^{-}$

506-78557-2

Dr. theol. Nina Frenzel war Stipendiatin des Cusanuswerks und wissenschaftliche Mitarbeiterin am Seminar für

Liturgiewissenschaft der Universität Bonn. Seit Mai 2017 ist sie Lehrerin für Katholische Religionslehre und Latein an der Erzbischöflichen Liebfrauenschule in Köln.

For more information see brill.com

Order information: Order online at brill.com +44330 3330049 | customerservices@brill.com Submission information: brill.com/authors

Titles published by Brill | Fink, Brill | mentis or Brill | Schöningh: +49(o)71 5413279216 | brill@brocom.de 